\title{
Effects of Propranolol on Blood Sugar, Insulin and Free Fatty Acids*
}

\author{
S.P. Alisson, M.J. Chamberlain, J.E. Mmler, R. Ferguson, A.P. Gituett, B. V. Bemand \\ and R.A. SAUNDERS
}

Departments of Medicine and Experimental Pathology, University of Birmingham,

Received: February 10, 1969

\begin{abstract}
Summary. Three types of experiment were carried out in normal subjects to determine the effect of therapeutic doses of oral Propranolol on 1. the blood sugar, plasma insulin and free fatty acids (FFA) during prolonged fasting and exercise, 2 . intravenous glucose tolerance and the rise in insulin level after intravenous glucose, and 3 . the intravenous glucose tolerance on exercise. Propranolol caused only slight lowering of the blood sugar in normals, even after $24 \mathrm{~h}$ fasting. This was most noticeable during exercise. There was no significant effect of Propranolol on fasting insulin levels, on glucose tolerance at rest or exercise, or on the response of plasma insulin levels to intravenous glucose. Lowering of plasma FFA levels was found in all subjects when taking Propranolol particularly during and aftor exercise. Possible mechanisms of hypoglycaemia in those cases reported in the literature are discussed. It is concluded that hypoglycaemia is not a major problem in Propranolol therapy.
\end{abstract}

Effets du propranolol sur la glycémie, l'insuline et les acides gras libres

Résumé. Trois types d'expérience ont été effectués chez des sujets normaux afin de déterminer l'effet de doses thérapeutiques orales de propranolol sur 1. la glycémie, l'insuline et les acides gras libres (FFA) du plasma au cours du jeûne prolongé et de l'exercice, 2. la tolérance au glucose intraveineux et l'augmentation du taux d'insuline après glucose intraveineux, et 3. la tolérance au glucose intraveineux pendant l'exercice. Lo propranolol ne provoquait qu'un léger abaissement de la glycémie chez les sujets normaux, même après $24 \mathrm{~h}$ de jeûne. Ceci était plus décelable au cours de l'exercice. Le propranolol n'exerçait aucun effet significatif sur les taux d'insuline à jeun, la tolérance au glucose au repos ou en cours d'exercice, ou sur la réponse des taux d'insuline plasmatique au glucose intraveineux. On a observé un abaissement des taux de FFA plasmatiques chez tous les sujets après absorption de propranblol, particulièrement au cours ou après un exercice. Les mécanismes possibles d'hypoglycémie dans les cas décrits dans la littérature sont discutés. Les auteurs concluent que l'hypoglycémie n'est pas un problème majeur dans la thérapeutique par le propranolol.

Wirkung von Propranolol auf Blutzucker, Insulin und freie F'ettsäuren

Zusammenfassung. Bei Normalpersonen wurden die Effekte von oral verabreichten Dosen von Propanolol in 3 verschiedenen Versuchsanordnungen überprüft: 1. auf Blutzucker, Plasmainsulin und freie Fettsäuren (FFS) während längerer Fastenperioden und unter körperlicher Belastung, 2. auf die Glucosetoleranz und den Anstieg der Seruminsulinspiegel nach i.v. Glucosezufuhr, 3. auf die i. v. Glucosetoleranz bei Muskelarbeit. Propranolol senkte den Blutzucker bei Normalpersonen auch nach 24-stündigem Fasten nur geringfügig. Dies war besonders auffällig unter körperlicher Belastung. Es ließen sich keine signifikanten Propanolol-Effekte auf die Nüchterninsulinspiegel, auf die Glucosetoleranz in Ruhe und bei Musekelarbeit und auf den Anstieg der Plasmainsulinspiegel nach i.v. Glucosegabe nachweisen. Bei allen Probanden führte Propanolol zu einer Senkung der Plasma FFS-Spiegel, vor allem während und nach Muskelarbeit. Mechanismen, die die in der Literatur beschriebenen Beobachtungen von Hypoglykämien nach Propanolol ausgelöst haben könnten, werden diskutiert. Es wird gefolgert, daß Hypoglykämien bei der Propanolol-Therapie kein größeres Problem darstellen.

Key-words: Propranolol, blood-clucose, Free-fatty acids, Plasma-Insulin, glucose-tolerance, exercise.

\section{Introduction}

There have been several reports of hypoglycaemia in patients treated with Propranolol (KoTLER et al., 1966; Mackintosh, 1962). Reveno and Rosendadum (1968) treated four insulin-dependent diabetics with Propranolol in dosages from 20 to $120 \mathrm{mg}$ per day. An increase in hypoglycaemic reactions was noted in two of these patients.

However Frtzgarald (Personal communication 1968) reports that "A survey of approximately 80000 diabetic patients carried out under the auspices of the British Diabetic Association, revealed that 152 patients were receiving Propranolol. In none of these patients was a hypoglycaemic action of Propranolol demon. strated".

* These studies were carried out as part of an elective period in the Departments of Medicine and Experimental Pathology in the University of Birmingham.
Experiments have been performed to elucidate the role of Propranolol in producing hypoglycaemia. Abramson et al. (1966) concluded "Propranolol affected neither the rate nor the extent of fall of plasma glucose during the insulin tolerance tests but dampened its subsequent rebound". They also showed that Propranolol blocked the rebound in FFA's induced by hypoglycaemia. Bewsher (1967) fasted 6 healthy volunteers and subjected them to 9 min hard exercise after $40 \mathrm{mg}$ Propranolol. He showed that there was no change in the resting blood sugars, but that Propranolol caused lower blood sugars in the post-exercise period. The levels attained were not such as to cause clinical manifestations of hypoglycaemia. Sussuan et al. (1967) reported that Propranolol infusion stimulated insulin release by the isolated perfused rat pancreas, and suggested that Propranolol "Can be a potent stimulator of insulin secretion, and that the hypoglycae- 
mia observed in the subjects reported may have been due to raised circulating insulin levels".

There is therefore conflicting evidence, firstly on the extent of the danger of inducing hypoglycaemia in patients treated with Propranolol, and secondly on the mechanism by which hypoglycaemia is produced. The present study was designed to resolve some of these conflicting views.

\section{Methods}

Three different experiments were performed on normal male volunteers of average height and weight between the ages of 20 and 30 years. All volunteers had been on a normal diet up to the time of the study.

Experiment 1: 4 subjects were fasted from 7.0 p.m. on the evening before the study until $7.0 \mathrm{a} . \mathrm{m}$. on the day of the study. Venous blood was taken at 15, 17, 19, 21 and $22 \mathrm{~h}$ fasting. Between these times the subjects went about their normal daily work as medical students, but before each venepuncture the subjects sat at rest for $15 \mathrm{~min}$. After $22 \mathrm{~h}$ fasting a forearm vein was cannulated, and the cannula kept patent by in. fusion of normal saline. The subjects then walked for

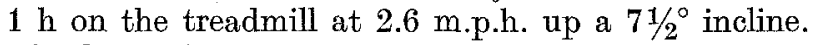
Blood samples were withdrawn every $10 \mathrm{~min}$ through a three way tap attached to the intravenous catheter. At the end of the exercise periods, the subjects rested for an hour, and further blood samples were taken at 10 , 30 and $60 \mathrm{~min}$ after the end of exercise. This protocol was followed with each subject once without Propranolol as a control, and once with $200 \mathrm{mg}$ of the drug taken orally in divided doses at times $0,4,13,17,21 \mathrm{~h}$ of the fast. In 2 subjects the Propranolol study was performed before the control one, to eliminate the effect on the results of the subjects becoming accustomed to the procedure.

Blood for the determination of plasma immunoreactive insulin and $\mathrm{FFA}$ was taken into dry, sodium heparin tubes and separated immediately. Plasma samp. les for FF A were frozen at $-20^{\circ} \mathrm{C}$ and treated the following day in duplicate by Dole (1960) double extraction followed by the Duncombe (1963) colorimetric estimation. A storage study showed no change in FFA levels in samples stored for $24 \mathrm{~h}$. Plasma for insulin estimation was kept at $-20^{\circ} \mathrm{C}$, for $1-2$ weeks until both control and Propranolol studies had been completed in each subject, enabling the samples from both studies to be estimated in the same batch. Assay was in triplicate by a modification of the method of HALES and RANDLE (1963).

Samples for blood sugar estimation were taken into fluoride tubes, stored overnight at $4^{\circ} \mathrm{C}$ and estimated in duplicate the following morning by the 'Neocuprin' Autoanalyser technique. A storage study showed no deterioration in such samples stored for over $24 \mathrm{~h}$.

Experiment 2: A similar protocol to Experiment 1 was followed in 4 subjects, except that at $22 \mathrm{~h}$ fasting the subjects were given a standard intravenous glucose tolerance test at rest instead of an hour's exercise.
25 grams of glucose was given intravenously in $50 \mathrm{~g} /$ $100 \mathrm{ml}$ soln. over $3 \mathrm{~min}$. Blood samples were taken at the same times as in Experiment 1 during the fasting period, but at $5,10,20,30,40,50$ and $60 \mathrm{~min}$ during the GTT. Blood samples were treated and estimated for sugar and insulin the same way as in Experiment 1. Glucose tolerance was expressed as the rate of disappearance of glucose from the peripheral blood or $K$ value (SAMols and Marks, 1965). Propranolol was given orally at the same times as in Experiment 1, but in graded doses, i. e. Subject $1-100 \mathrm{mg}$, Subject 2 $200 \mathrm{mg}$, Subject 3 - $400 \mathrm{mg}$, Subject $4-600 \mathrm{mg}$.

Experiment 3: 3 subjects were fasted for $20 \mathrm{~h}$ from 7.0 p.m. the day before the study, and at $20 \mathrm{~h}$ a standard 25 gram intravenous G'T $T$ was performed, in the first study at rest, in the second during an hour's exercise on the treadmill but after taking Propranolol $100 \mathrm{mg}$ in divided doses over the previous $20 \mathrm{~h}$. Blood sugar only was estimated.

\section{Results}

Experiment 1: The mean values of FFA, blood sugar and plasma insulin are shown in Fig. 1. The levels of

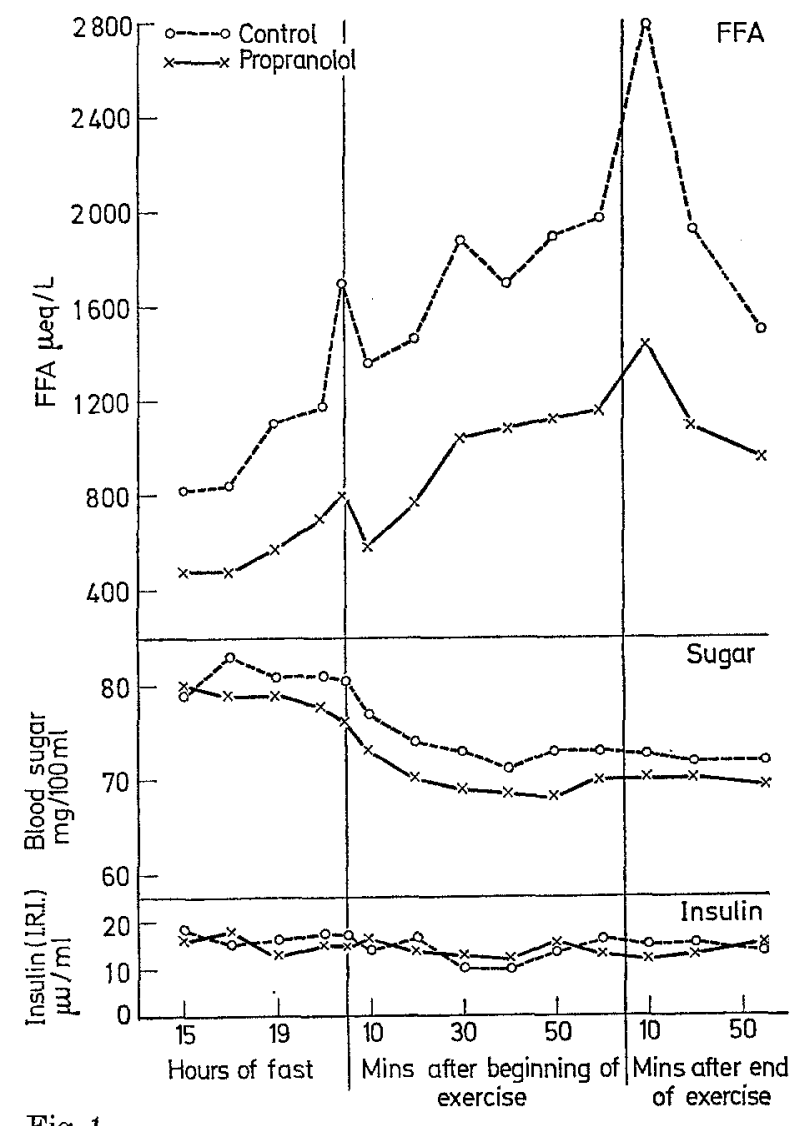

Fig. 1.

FFA were markedly lower throughout the Propranolol study compared with the control one. In particular, the rebound after exercise was largely suppressed by Propranolol. 
The blood sugar levels on Propranolol were slightly but consistently lower than in the control study, particularly on exercise, although at no time did the concentration of blood sugar on Propranolol fall to a level likely to produce symptoms. There was no difference in insulin (IRI) levels between the Propranolol and control study.

Statistical comparison between curves of the type shown in Fig. 1 are difficult, and there is no satisfactory simple technique. Student's $t$ test applied to the values at any one time is an inefficient method although widely used.

Applied to the data in Fig. 1, neither the $t$ test nor an analysis of variance indicated a statistically significant difference between any of the pairs of curves, presumably because the extent of the differences varied widely between individuals. However, the differences for FFA and sugar are so consistent and, in the case of FFA, so large, that there is a strong supposition that they are unlikely to be due to chance alone.

Experiment 2: (see Table 1) Very slightly lower fasting blood sugars were seen on Propranolol, but there was no consistent difference in the $K$ value of the GTT or in the insulin (IRI) response to intravenous glucase between the control and Propranolol studies. go a $21 / 2$ mile walk up a $7 \frac{1}{2}$ incline at the end of the day. This lends support to the view that this drug does not have a direct hypoglycaemic action, but may make hypoglycaemia from some other cause persist by blocking compensatory mechanisms. We have also excluded any effect of Propranolol on insulin levels and on the insulin response to glucose. The GTT is unaffected, and although in Experiment 3 we have not measured insulin levels, NIкkп्̈ et al. showed that there was no difference in the insulin response to intravenous glucose between the resting and exercising state, but that the improvement in glucose tolerance during exercise must be due to some other factor. We found no difference in the exercise GTT with or without Propranolol, suggesting that this factor is unrelated to $\beta$ adrenergic activity, and further it seems unlikely that there was any influence of Propranolol on insulin levels under these circumstances.

It is possible that the hypoglycaemia reported in patients on Propranolol is partly caused by blocking the mobilization of muscle glycogen, and hence release of lactate for hepatic gluconeogenesis. It is also possible that some part is played by the lowering of plasma FFA levels. This might enhance glucose utilization by affecting the glucose-FFA cycle (RANDLE et al., 1965). The concomitant lowering of glyeerol levels (ABRAHAMSON

Table 1

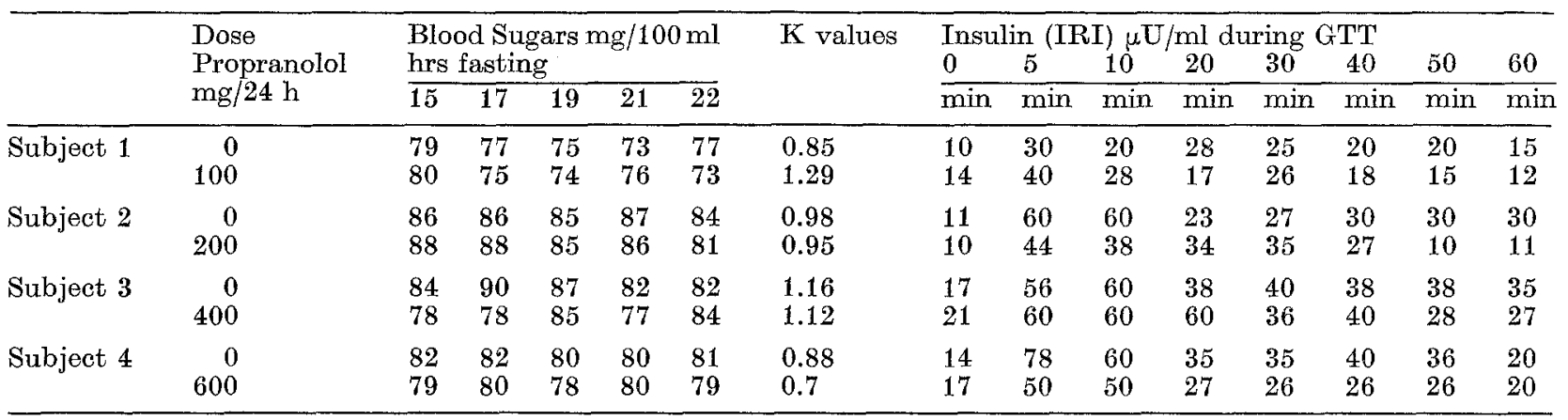

Experiment 3: (see Table 2). The marked increase in $\mathrm{K}$ value between rest and exercise GTT's described by NIKkILÄ et al. (1968), was seen in this experiment, but the addition of Propranolol did not significantly alter the exercise GTT.

Table 2. $K$ values (Experiment 3)

\begin{tabular}{llll}
\hline & Rest & Exercise & $\begin{array}{l}\text { Exercise + } \\
\text { Propranolol }\end{array}$ \\
\hline Subject 1 & 0.75 & 2.17 & 1.93 \\
Subject 2 & 1.16 & 1.74 & 1.51 \\
Subject 3 & 1.07 & 1.74 & 1.93 \\
\hline
\end{tabular}

\section{Discussion}

These results indicate that in normal individuals doing an ordinary day's work, therapeutic doses of Propranolol do not cause significant hypoglycaemia, even when the subjects are starved for $24 \mathrm{~h}$ and under- et al., 1966) removes another precursor of hepatic gluconeogenesis. In a study in vitro, VIZI et al. (1965) found that phenoxybenzamine had no effect on glucose released from the perfused isolated rat liver, though dichloroisoprenaline, a $\beta$ blocker, abolished this release. HorNBroor and Brody (1963) found that phenoxybenzamine, dichloroisoprenaline or pronethalol blocked the activation of liver phosphorylase in the rat following intravenous infusion of adrenaline; whereas in skeletal muscle, phosphorylase activity was markedly depressed by dichloroisoprenaline or pronethalol but unaffected by phenoxybenzamine. There are clearly species differences however, for ANTonis et al. (1967) showed that in man the liver glycogenolysis induced by adrenaline is an $\alpha$ effect, whereas muscle glycogenolysis is a $\beta$ effect. They also demonstrated a blocking by Propranolol of the adrenaline-induced rise in lactate in the fasting human subject. It seems probable, there- 
fore, that, in man, hypoglycaemia from Propranolol is unlikely to occur until liver glycogen supplies are exhausted, and glucose from gluconeogenesis becomes a critical factor in maintaining the level of the blood sugar.

The FFA levels in the control fasting period in Experiment 1 are rather higher than the normal levels usually described. This is probably due to two factors. Firstly our subjects were physically active and not at rest during this period, and secondly they had already fasted 15 hours by the time the first sample was taken at $10.00 \mathrm{a} . \mathrm{m}$. The first of these factors might be expected to be counteracted by $\beta$ blockade, and this would explain the lower fasting levels found on Propranolol. The gradual rise of FFA levels with increasing length of fast is as expected. The rise in FFA just preceding exercise is presumably an effect of apprehension. These results emphasize the importance, when stating normal levels of FFA, of defining precisely the length of fast and the conditions of activity and emotional stimulus under which the blood samples are taken.

It is concluded that hypoglycaemia is unlikely to be a problem in patients treated with Propranolol unless, particularly in the case of children, they are subjected to prolonged fast or are likely to suffer from hypoglycaemia due to another cause.

\section{Acknowledgements}

We should like to thank Dr. J.D. FitzGeraId of I.C.I. Pharmaceuticals division for his advice and support and Dr. R.F. Fletcher and Professor John Hardwicke for their helpful criticism. Dr. JoHn Date kindly helped us with the statistical computation. We acknowlege the kind help of Professor T.P. WHITEHEAD and the Department of Clinical Biochemistry of the Queen Elizabeth Hospital, Birmingham in measuring the blood sugars.

We thank Miss Anne Unitr and Mrs. Christine HAYNes for their invaluable technical help.

The help of the Medical Research Council in supporting one of us (S.P.A.) is gratefully acknowledged.

\section{References}

Abramson, E.A., R.A. Arky, and K.A. Womber: Effects of Propranolol on the Hormonal and Metabolic Responses to Insulin Induced Hypoglycaemia. Lancet 1966 II, $1386-1388$.
Antonis, A., M.L. Clarke, R.L. Hodge, M. Molony, and T.R.E. PILkINGTon: Receptor Mechanisms in the Hyperglycaemic response to Adrenaline in Man. Lancet 1967 I, $1135-1137$.

Bewsher, P.D.: Propranolol, Blood sugar and exercise. Lancet 1967 I, 104.

Cockran, B. Jr., E. P. Marbach, R. Poucher, T. StreinBERG, and G. GwrNup. Effect of Acute Muscular Exercise on Serum Immunoreactive Insulin Concentration. Diabetes 15, 838-841 (1966).

Dole, V.P., and H. Meinertz: Microdetermination of Long-chain Fatty acids in Plasma and tissues. J. biol. Chem. 235, 2595-2599 (1960).

Duncombe, W.G.: The Colorimetric Micro-determination of Long chain Fatty acids. Biochem. J. 88, 7-10 (1963).

Fitzgerald, J.D.: Personal communication.

HALES, C.N., and P.J. RANDIE: Immunoassay of Insulin with Insulin-Antibody Precipitate. Biochem. J. 88, $137-146$ (1963).

Hornbrook, K.R., and T.M. Brody: Phosphorylase activity in rat liver and skeletal muscle after catecholamines. Biochem. Pharmacol. 12, 1407-1415 (1963).

Kotler, M.N., L. Berman, and A.H. RuBtnstein: Hypoglycaemia precipitated by Propranolol. Lancet 1966 II, $1389-1390$.

Mackintosh, T.E.: Propranolol and Hypoglycaemia. Lancet 1967 I, $104-105$.

Nikkilä, E.A., M.R. Taskinen, T.A. Mietimen, R. Pelkonen, and H. Poppius. Effect of Muscular exercise on Insulin Secretion. Diabetes 17, 209-218 (1968).

Randle, P.J., P.B. Garland, C.N. Hales, and E.A. Newsholme. The Glucose-Fatty acid cycle, its role in Insulin sensitivity and the metabolic disturbances of Diabetes Mellitus. Lancet 1963 I, 785-789.

Reveno, W.S., and H. Rosenbaum. Propranolol and Hypogiycaemia. Lancet 1968 I, 920.

SAMOLS, E., and V. MARKS: Interpretation of the Intravenous Glucose test. Lancet 1965 I, 462.

Sussman, K.E., M.R. STJERnholm, and G.D. VaughaN. Propranolol and Hypoglycaemia. Lancet 1967 I, 626.

VizI, E.S., G. Pogatsa, and A. KaIdor. On Sympathetic regulation of carbohydrate metabolism in the liver. J. Pharm. (Lond.) 17, 805-808 (1965).
S.P. Allison
Clinical Research Fellow
Department of Medicine
University of Birmingham
Birmingham, Great Britain 